Koczur, L. M., B. M. Ballard, M. C. Green, D. G. Hewitt, and S. E. Henke. 2018. Breeding ecology and habitat use of North America's rarest Ardeidae: the Reddish Egret Egretta rufescens. Avian Conservation and Ecology 13(2):10. https://doi.org/10.5751/ACE-01258-130210

Copyright (C) 2018 by the author(s). Published here under license by the Resilience Alliance.

Research Paper

\title{
Breeding ecology and habitat use of North America's rarest Ardeidae: the Reddish Egret Egretta rufescens
}

\author{
Lianne M. Koczur ${ }^{1}$, Bart M. Ballard ${ }^{1}$, M. Clay Green ${ }^{2}$, David G. Hewitt ${ }^{1}$ and Scott E. Henke ${ }^{1}$ \\ ${ }^{1}$ Caesar Kleberg Wildlife Research Institute, Texas A\&M University-Kingsville, ${ }^{2}$ Department of Biology, Texas State University
}

\begin{abstract}
The Reddish Egret (Egretta rufescens) remains underrepresented in waterbird research despite its status as the rarest heron in North America and a near-threatened species. The Reddish Egret is also a habitat specialist, and is restricted to shallow, coastal wetlands throughout its range. We utilized GPS-equipped platform terminal transmitters to examine the breeding ecology of Reddish Egrets $(n=28)$ in Texas. Although individuals exhibited varying degrees of fidelity to specific colonies, there was fidelity to particular areas within the Laguna Madre, Texas, across years. Reddish Egrets also exhibited fidelity to foraging areas across years and selected nonvegetated tidal flats as foraging habitat. Long-distance migrants began the breeding season two weeks later than residents on average; however, the timing of breeding did not appear to influence nest success. We also found that the amount of available foraging habitat within $15 \mathrm{~km}$ of the colony was associated with the abundance of Reddish Egret breeding pairs at colonies.
\end{abstract}

\section{Écologie de reproduction et utilisation d'habitat de l'Ardéidé le plus rare d'Amérique du Nord : l'Aigrette roussâtre Egretta rufescens}

RÉSUMÉ. L'Aigrette roussâtre (Egretta rufescens) demeure sous-représentée dans les recherches sur les oiseaux aquatiques malgré son statut de héron le plus rare d'Amérique du Nord et d'espèce quasi menacée. L'Aigrette roussâtre est aussi une spécialiste d'habitat et fréquente uniquement les milieux humides côtiers peu profonds dans l'ensemble de son aire de répartition. Nous avons utilisé des émetteurs balises équipés de GPS pour examiner l'écologie de reproduction d'Aigrettes roussâtres $(\mathrm{n}=28)$ au Texas. Bien que les individus aient montré un degré de fidélité variable aux colonies elles-mêmes, ils ont été fidèles à des endroits particuliers dans la Laguna Madre, Texas, d'une année à l'autre. Les aigrettes ont aussi été fidèles aux aires d'alimentation au fil des ans, des zones intertidales sans végétation. Les individus migrateurs de longue distance ont commencé leur saison de reproduction deux semaines plus tard que les individus résidents en moyenne; toutefois, la phénologie de nidification n'a pas semblé avoir un effet sur le succès de nidification. Nous avons également observé que la superficie d'aires d'alimentation dans un rayon de $15 \mathrm{~km}$ d'une colonie était associée au nombre de couples nicheurs d'Aigrettes roussâtres qui s'y trouvaient.

Key Words: breeding; Egretta rufescens; habitat use; Reddish Egret; Texas

\section{INTRODUCTION}

The Reddish Egret (Egretta rufescens) population was greatly diminished in the late 1800s because of plume hunting and egg collection, but with the passing of the Migratory Bird Treaty Act in 1918 the population began to increase in the United States (Wilson et al. 2014). The species' range includes coastal wetlands along the Gulf of Mexico coast from the southern United States into northern South America, along the Pacific Coast of Mexico, and throughout the Caribbean (Lowther and Paul 2002). The global population of mature individuals has been estimated at 5000-11,300 (Wilson et al. 2014, BirdLife International 2016). The Texas population of egrets, estimated at $\sim 2,000$ breeding adults, may account for $\sim 20-40 \%$ of the total population. Due to the small population size and a distribution restricted to coastal habitats, the Reddish Egret is listed as near-threatened by the IUCN (BirdLife International 2016) and as a threatened species in the state of Texas. The Reddish Egret is a species of conservation concern across much of its range; however, knowledge of its breeding ecology is limited.
Records of Reddish Egret observations in Texas can be found from as early as 1837 (R. T. Paul 1991, unpublished report). Currently, the highest breeding densities of Reddish Egrets occur along the central and lower Texas coast, with the majority occurring in the Laguna Madre in just seven colonies (Green 2006; Texas Colonial Waterbird Society, unpublished data). The Texas Colonial Waterbird Society (TCWS) has conducted breeding pair surveys in Texas since 1973, which provide information on the numbers and locations of breeding egrets. There was an overall decrease in breeding pairs from 1973 to 2007; however, numbers fluctuate greatly from year to year (Turner 2011). Whereas survey data document the colonies used every year, there has not been any examination of individual site fidelity to breeding colonies.

Much of the previous research on Reddish Egrets during the breeding season has focused on nest success. There have been a small number of attempts to examine Reddish Egret nesting ecology in Texas (McMurry 1971, Simersky 1971, Huysman 1995) and a recent study that investigated reproductive success (Holderby et al. 2012). In the broader scope of herons, 
considerable research has been conducted on colony use and productivity, particularly in relation to foraging habitat (e.g., Gibbs 1991, Smith 1995, Tourenq et al. 2004, Kelly et al. 2008). These studies have revealed the fundamental importance that the composition of habitats proximal to waterbird colonies has on colony use, species composition, and productivity. Foraging habitat may be an important component of the breeding ecology of Reddish Egrets; egrets nesting in Florida appear to select nesting islands in close proximity to foraging sites (Hill and Green 2011). The spatial and temporal availability of foraging habitat of Reddish Egrets were recently examined in the Laguna Madre of Texas (Bates et al. 2016), permitting investigation into the relationship between colony use and proximity to foraging habitat, and fidelity to these areas. In order to better understand the breeding ecology of Reddish Egrets in Texas, our research objectives were to use locations of adult Reddish Egrets marked with GPS-equipped platform terminal transmitters to examine foraging habitat use during the breeding season, and to determine site fidelity to foraging areas and breeding colonies.

\section{METHODS}

\section{Study area}

The Laguna Madre, Texas, is a shallow, hypersaline lagoon with an average water depth of $\sim 1 \mathrm{~m}$ (Tunnell and Judd 2002). It contains extensive areas of seagrass and wind-driven tidal flats. The Laguna Madre is bordered on the east by a barrier island, including the undeveloped Padre Island National Seashore and the developed South Padre Island (Tunnell and Judd 2002). On the mainland side, undeveloped private rangeland predominates, and Laguna Atascosa National Wildlife Refuge borders the southern Laguna Madre. Other land uses on the mainland side include row crop agriculture, cattle ranching, wind energy production, and suburban developments. Because the surrounding land is largely private or federally owned, there is limited boat access to the Laguna Madre; however, the Gulf Intracoastal Waterway extends the length of the lagoon providing access for commercial and recreational activities. The Laguna Madre is divided into the upper and lower Laguna Madre, which are separated by the land-cut, a large expanse of tidal flats that forms a land-bridge from Padre Island to the mainland (Tunnell and Judd 2002; Fig. 1A and 1B). The Laguna Madre contains six natural islands and numerous dredge spoil islands that are used by colonial nesting species. Two of the nine islands on which egrets were trapped had cabins and people fished from or near all these islands.

\section{Capture and transmitters}

Reddish Egrets were trapped at nine colonies in the Laguna Madre, Texas. Actively nesting adult Reddish Egrets $(n=28)$ were trapped in late May-June during the 2010-2012 and 2014 breeding seasons. Egrets were trapped using modified noose mats placed within $1 \mathrm{~m}$ of the nest. Specific colonies and nests were chosen based on the number of other birds nesting on the island, location of the nest in relation to other species, and accessibility of the nest to minimize disturbance to other nesting birds. Egrets were trapped during mid- to late incubation to minimize the possibility of nest abandonment. We recorded morphometric measurements and color morph, and affixed a United Sates Geological Survey aluminum leg band and a colored, alphanumeric plastic leg band to each individual. Solar-powered
GPS platform terminal transmitters (PTT-100, Microwave Telemetry, Inc.) weighing $22 \mathrm{~g}$ were attached with Teflon ribbon as a backpack-style harness. Transmitters were $\leq 3.0 \%(n=24)$ and $3.0-3.2 \%(n=4)$ of total body weight (range: $680-1025 \mathrm{~g})$ and were accurate to $\leq 18 \mathrm{~m}$. Total handling time was $<30 \mathrm{~min}$. Previous observations of Reddish Egrets in the Laguna Madre found peaks in foraging activity to occur around 08:30 $\mathrm{h}$ and 17:00 h (E. Bates, unpublished data). Consequently, transmitters were set to record locations six times per day at 08:00, 09:00, 16:00, 17:00, 24:00, and 01:00 h, coinciding with peak foraging times and nocturnal roosting. Locations were downloaded once weekly from the Argos system (http://www.argos-system.org/) and automatically to MoveBank. We collected blood samples from eight egrets in 2014 and used a Puregene DNA Purification Kit (Qiagen, Valencia, CA) blood tissue protocol to extract genomic DNA. We also collected seven carcasses during the study period and used the solid tissue protocol to extract genomic DNA from footpad skin, feathers, and powdered bone. We used discriminant analysis in SAS 9.2 (SAS Institute, Inc. 2008, Cary, NC) based on the measurements and known sex of these 15 individuals to determine sex of 13 egrets that we did not have a DNA sample for (for detailed methods see Koczur et al. 2015).

Fig. 1. Location of seven breeding colonies in the upper (A) and two in the lower (B) Laguna Madre, Texas, where Reddish Egrets (Egretta rufescens) were trapped during 2010-2014.

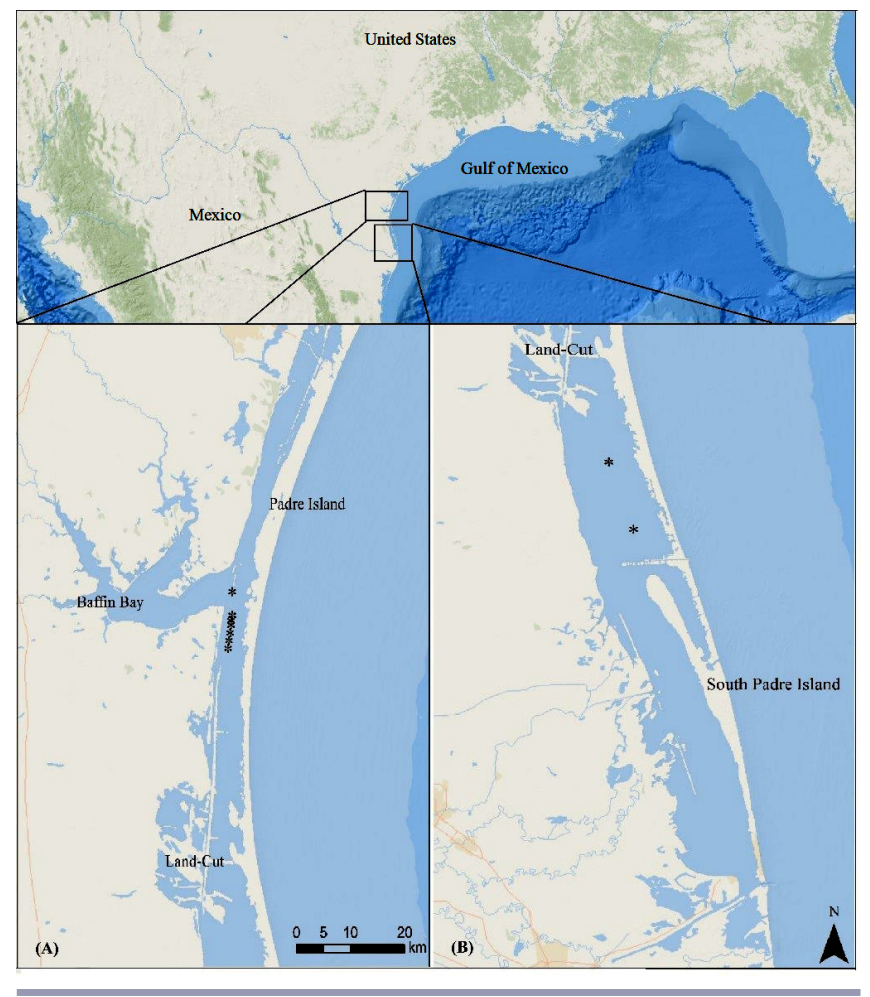

\section{Timing of breeding and nest success}

The breeding season occurred during March-August for all marked Reddish Egrets. We estimated the initiation date of nesting behavior by using the first day that an egret began to consistently show up at a colony. There is no published literature on the duration of nest building for Reddish Egrets; however other 
heron species average 3-5 days (Jenni 1969, Rodgers 1980). Reddish Egrets have an average clutch size of 3.1 eggs and lay one egg every other day (McMurry 1971). Therefore, if an egret was consistently on a colony for at least two weeks it was assumed to be nesting. The least square mean (LSM) Julian date of breeding behavior initiation was used to examine differences in initiation dates between residents (those individuals that remained in the Laguna Madre of Texas during winter) and migrants (those individuals that departed the Laguna Madre of Texas during winter). Migrants were further subdivided into those that exhibited postbreeding dispersal/migrated short-distances (50$200 \mathrm{~km})$ and those that migrated long-distances $(>500 \mathrm{~km})$ out of the Laguna Madre, Texas. We compared differences in initiation dates between residents and migrants using Welch's twosample t-test and considered differences significant if $\mathrm{P}<0.05$.

The incubation period for the Reddish Egret averages 26 days (R. T. Paul 1991, unpublished report); therefore, if the GPS locations of an individual were at the colony for $\geq 36$ consecutive days (five days for courtship/nest construction, five days for egg laying, 26 days for incubation) the nest was assumed to have successfully hatched. Chicks remain at the nest for 4-5 weeks after hatching and do not disperse from the natal colony until $\sim 12$ weeks after hatching (Bates et al. 2015), during which time the adults provision the fledglings ( $\mathrm{R}$. T. Paul 1991, unpublished report). If the egret was at the colony $<36$ days, the nest was assumed to have failed. Reddish Egrets may renest after nest failure (McMurry 1971); thus, if locations showed up on another colony in a fashion consistent with nesting, it was assumed the egret attempted to renest.

\section{Colony fidelity}

We used location data to determine fidelity to breeding colonies across years and report the number of colonies used by each individual that provided $\geq$ two years of location data during the breeding season. We report the number of years nesting activity was presumed, the number of colonies used during those years, and the average distance $(\mathrm{km})$ between nesting colonies. We also used the TCWS survey data to examine colony stability over time, specifically for colonies where marked Reddish Egrets nested. For the metric of stability, we used data from surveys conducted in 2000-2014 and recorded the number of years that waterbird nesting occurred on each island as a proportion of the 15 years. If data were not collected in all years, the total number of years that data were available was used for the basis of the proportion. In a few situations when a colony was not surveyed in a particular year, yet GPS locations showed egrets to be nesting at that colony, we recorded that colony as active for breeding Reddish Egrets in that year.

\section{Foraging habitat}

We assessed foraging habitat selection using locations of marked Reddish Egrets not in the colony during foraging times (i.e., 08:00, 09:00, 16:00, 17:00 h). We assessed the benthic habitat at these foraging locations using a benthic habitat data set (National Oceanic and Atmospheric Administration) in ArcMap 10.3.1 (ESRI 2011). Predominant benthic habitats in the Laguna Madre included the following: unconsolidated sediment $(<10 \%$ seagrass coverage), patchy seagrass $(10-75 \%$ seagrass coverage), continuous seagrass (76-100\% seagrass coverage), land (areas above high-tide line), and unknown habitat, which were areas that were not able to be classified (Finkbeiner et al. 2009). All of the foraging locations during the breeding season were used to assess whether a particular benthic habitat type was used for foraging. The package adehabitatHS 0.3.12 (Calenge 2011) in Program R was used to calculate Manly selection ratios ( $w_{i}$; Manly et al. 2007) for benthic habitat types used during foraging. We used the Design III model, for which habitat use and availability are measured for each individual. We created convex hulls in ArcMAP using the minimum bounding geometry tool and all foraging locations for each individual to delineate available area.

We measured the closest distance to the mainland or barrier island for each foraging location in ArcMap. We also measured the distance that each foraging location was from the breeding colony during the period that the bird was assumed to be nesting or provisioning young. The period that the bird was at a colony was divided into four time periods: early (weeks 1-2), incubation (weeks 3-6), brooding (weeks 7-10), and fledging (weeks 11+). For the year that an individual was captured, we assumed it was in the middle of the incubation period because birds had a complete clutch and were actively incubating upon capture. We calculated the average flight distance across years and within stages, then examined differences in mean flight distances from the breeding colony to foraging areas among sex, nesting stage, and area of the Laguna Madre (upper or lower). We modeled all main effects and all two- and three-way interactions in SAS 9.4 using a three-factor ANOVA with repeated measures (Proc MIXED; SAS Institute, Inc. 2008, Cary, NC).

To assess fidelity to foraging areas, we measured home range overlap across successive and nonsuccessive years using the adehabitatHR package 0.4.14 (Calenge 2015) in Program R. Bhattacharyya's Affinity Index (BAI) was used as an index of overlap, with zero being no overlap and one being complete overlap (Fieberg and Kochanny 2005). We also measured overlap of home ranges between the time period a bird was at a colony and the postbreeding period after it left the colony to determine if egrets utilized different foraging areas after nesting.

Last, we examined the relationships between the amount of available foraging habitat and the density of competitors around each colony on breeding pair abundance of Reddish Egrets for 22 colonies in the Laguna Madre. Available foraging habitat was previously modeled for the Laguna Madre based on bathymetry, tide gauge readings, and benthic habitat (Bates et al. 2016) for the years 2010-2013. We created buffers around each colony at a 15$\mathrm{km}$ radius and used the spatial models of Bates et al. (2016) to calculate the area of foraging habitat within each buffer. We chose $15 \mathrm{~km}$ to be the radius of our landscapes around colonies because it was the mean foraging flight distance of transmittered Reddish Egrets from colonies in this study. We also calculated a metric of foraging competition. We used breeding survey data (TCWS, unpublished data) during 2010-2013 and calculated the average number of all heron species, i.e., Reddish Egret, Great Egret (Ardea alba), Great Blue Heron (A. herodias), Little Blue Heron (E. caerulea), Snowy Egret (E. thula), Black-crowned Night-heron (Nycticorax nycticorax), Yellow-crowned Night-heron (Nyctanassa violacea), and Tricolored Heron (E. tricolor), at each colony. We used ArcMAP 10.3.1 (ESRI 2011) to determine the amount of unique foraging habitat (not occurring in another colony's $15-\mathrm{km}$ buffer) and the amount of shared foraging habitat within each 
15-km buffer of each colony. The density of competitors at unique foraging habitat was the number of birds at that colony divided by the area of unique foraging habitat within the buffer. If foraging area was overlapping for two or more colonies, the densities were added for the area of overlap. An average density of competitors potentially foraging within $15 \mathrm{~km}$ of each colony was calculated. Densities were categorized as low ( $0-10$ birds/ha), medium (11-20 birds/ha), and high ( $\geq 21 \mathrm{birds} / \mathrm{ha}$ ). We used the average number of Reddish Egret pairs from 2010-2013 for each of the 22 colonies (TCWS, unpublished data). We used a negativebinomial generalized model (Proc GENMOD; SAS Institute, Inc. 2008, Cary, NC) to examine whether the amount of available foraging habitat within $15 \mathrm{~km}$ of the colony and the density of competitors within $15 \mathrm{~km}$ of the colony were significant predictors of Reddish Egret breeding abundance. Only main effects were modeled. We used the Pearson $\mathrm{X}^{2}$ criterion to assess goodness of fit for each parameter.

\section{RESULTS}

\section{Timing of breeding and nest success}

Initiation of nesting behavior ranged from 11 March to 13 May across all birds and years, with average initiation dates for each bird ranging from 29 March to 8 May. The average nesting behavior initiation was 17 days later in migrants (23 April; $n=7$ ) than residents (6 April; $n=7$ ) across all years $(\mathrm{t}=2.78, \mathrm{df}=8.04$, $\mathrm{P}=0.02)$. Long-distance migrants $(n=5)$ arrived in the Laguna Madre from early March to late April, and the time between arrival and breeding initiation ranged from seven to 53 days (mean $=24.7)$. Ten of 38 total nests failed based on the number of days the egret was at the colony ( $<36$ days) and there were six possible renesting attempts (Table 1). There was not an obvious pattern of nest failure based on migratory status, as residents, shortdistance migrants, and long-distance migrants all exhibited similar rates of nest failures.

Table 1. Number of consecutive days an adult Reddish Egret (Egretta rufescens) was at a specific colony in the Laguna Madre, Texas, during the breeding period in 2011-2016 (<36 days likely indicates a nest failure).

\begin{tabular}{llcccccc}
\hline \hline ID & Migratory Status & 2011 & 2012 & 2013 & 2014 & 2015 & 2016 \\
\hline 49148 & Resident & 111 & 81 & 123 & $55^{\ddagger}$ & & \\
49149 & Short-distance & $60^{\dagger}$ & 69 & $62^{\dagger}$ & 46 & & \\
49150 & Long-distance & 53 & 70 & 38 & & & \\
49154 & Long-distance & 29 & 55 & 13 & & & \\
49194 & Resident & 69 & & & & & \\
49422 & Resident & 79 & & & & 78 & 87 \\
49164 & Resident & & $76^{\dagger}$ & 24 & 83 & 78 & \\
49195 & Long-distance & & & & 57 & & \\
49153 & Resident & & 78 & 10 & 71 & & \\
$49422 \mathrm{~b}$ & Short-distance & & & 64 & $46^{\dagger,}$ & & \\
129772 & Long-distance & & & & & $57^{\dagger}$ & 58 \\
129771 & Resident & & & & & 70 & 84 \\
$49166 \mathrm{~b}$ & Long-distance & & & & & $64^{\dagger}$ & 92 \\
$49196 \mathrm{~b}$ & Resident & & & & \\
\hline
\end{tabular}

\section{Colony fidelity}

Of the 28 marked egrets, 14 provided information for two or more years, allowing examination of site fidelity. Only one egret nested on the same colony for each of two consecutive breeding seasons (Table 2). Three egrets returned to a previously used colony in nonconsecutive years. Although the other 13 nested at more than one colony, many exhibited fidelity to either the upper or lower Laguna Madre and nested in colonies within those areas. Two egrets that were captured in the upper Laguna Madre nested in the lower Laguna Madre the next year and three egrets that initially nested in the upper Laguna Madre nested in bays north of the Laguna Madre in subsequent years. Residents and shortdistance migrants nested in colonies that were positioned closer to each other across successive years $(\mathrm{LSM}=8.7 \mathrm{~km})$ than did long-distance migrants $(\mathrm{LSM}=53.1 \mathrm{~km})$. Therefore, although short-distance migrants had similar BAI values as long-distance migrants to specific colonies, they exhibited higher fidelity to general areas than did long-distance migrants. Colony stability was relatively high (on average 0.94 for all species, 0.82 for Reddish Egrets) for colonies where we observed egrets nesting, and one colony with lower stability was only surveyed two of the 15 years. Fidelity to colonies did not appear to be related to colony stability (overall or within migratory status) as individuals with both high and low degrees of fidelity nested in colonies with both high and low stability.

Table 2. The number of years a Reddish Egret (Egretta rufescens) nested, number of nesting islands used, and the mean distance (km) between nesting colonies during 2010-2016.

\begin{tabular}{llllcc}
\hline \hline ID & Sex & $\begin{array}{l}\text { Migratory } \\
\text { Status }\end{array}$ & Years & Colonies & Distance \\
\hline 49164 & F & Resident & 6 & 4 & 5.2 \\
49148 & M & Resident & 5 & 2 & 0.9 \\
49153 & M & Resident & 4 & 2 & 13.7 \\
$49196 \mathrm{~b}$ & $\mathrm{~F}$ & Resident & 3 & 3 & 28.8 \\
129771 & $\mathrm{~F}$ & Resident & 3 & 2 & 0.9 \\
49422 & $\mathrm{M}$ & Resident & 2 & 1 & 0.0 \\
49194 & $\mathrm{~F}$ & Resident & 2 & 2 & 2.0 \\
49149 & $\mathrm{M}$ & Short-distance & 5 & 3 & 16.6 \\
$49422 \mathrm{~b}$ & $\mathrm{M}$ & Short-distance & 3 & 3 & 10.4 \\
129772 & $\mathrm{M}$ & Long-distance & 3 & 2 & 13.0 \\
49154 & $\mathrm{M}$ & Long-distance & 4 & 3 & 26.0 \\
49150 & $\mathrm{M}$ & Long-distance & 4 & 2 & 1.4 \\
49195 & $\mathrm{M}$ & Long-distance & 2 & 2 & 94.4 \\
$49166 \mathrm{~b}$ & $\mathrm{~F}$ & Long-distance & 2 & 2 & 90.4 \\
\hline
\end{tabular}

\section{Foraging habitat}

We used 27,817 foraging locations from 23 egrets to calculate Manly selection ratios among four habitat types within the Laguna Madre: unconsolidated sediment, patchy seagrass, continuous seagrass, and land. Other habitat types were excluded from the analysis because of either small areas or small sample size of egrets within that habitat; for example, mangrove habitat accounted for 278 ha $(0.1 \%)$ of the benthic habitat within the Laguna Madre and only eight locations occurred on that habitat type. Seven egrets were excluded from this analysis because the transmitter or nest failed $\leq$ one month after date of initiation of 
breeding activity. Reddish Egrets used unconsolidated sediment $\left(\mathrm{w}_{\mathrm{i}}=2.37, \mathrm{SE}=0.29\right)$ and patchy seagrass $\left(\mathrm{w}_{\mathrm{i}}=3.01, \mathrm{SE}=0.55\right)$ for foraging more than expected, and used continuous seagrass less than expected $\left(\mathrm{w}_{\mathrm{i}}=0.13, \mathrm{SE}=0.02\right)$. More than $44 \%$ of each individual's foraging locations across the breeding period was on unconsolidated sediment and smaller percentages on seagrass and land. Foraging locations were an average of $2.09 \pm 1.68 \mathrm{~km}$ from the mainland and ranged from $0.00 \mathrm{~km}$ to $7.72 \mathrm{~km}$. This included 4004 locations that the Benthic Habitat Dataset identified as mainland, but that included narrow inlets and shallow areas on the shoreline that would flood during high tides.

The median flight distance from the colony to foraging sites of 8455 foraging locations from all birds combined was 9.47 (Median Absolute Deviation $=9.09) \mathrm{km}$ and the mean was $14.72(\mathrm{SD}=$ 16.46) $\mathrm{km}$. There was a significant three-way interaction among sex, area of the lagoon, and nesting stage $\left(F_{3,23.1}=5.52, \mathrm{P}=0.005\right)$. In the lower Laguna Madre, females flew shorter distances in the early nesting stage compared to all other stages, and males flew farther in the early and incubation stages compared to the brooding and fledging stages (Fig. 2). Within each nesting stage, there was no significant difference between males and females. In the upper Laguna Madre, there was no effect of nesting stage or sex on flight distances (Fig. 3). Average foraging distance by colony ranged from 3.8 to $44.2 \mathrm{~km}$.

Fig. 2. Average distance ( $\pm 95 \%$ confidence interval) flown from the colony to foraging sites of adult Reddish Egrets (Egretta rufescens) breeding in the lower Laguna Madre, Texas, during 2010-2016. P-values for within stage comparisons between sexes are indicated above bars, differences among stages within a sex are indicated by letters.

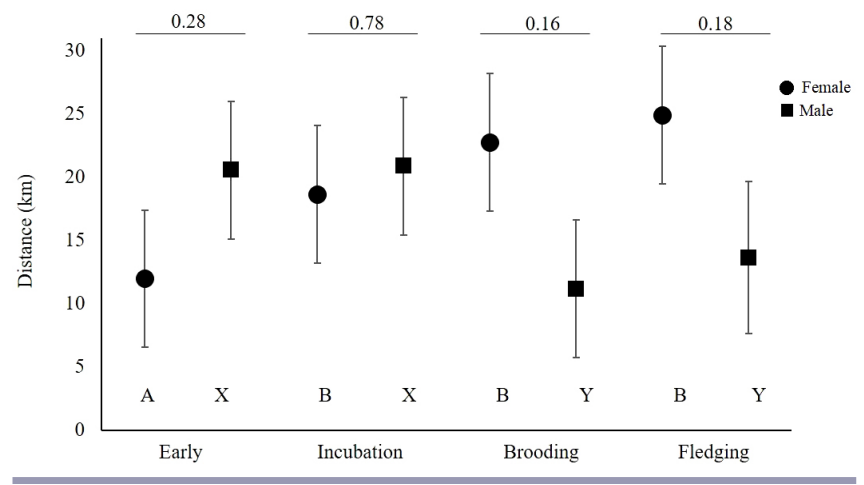

Reddish Egrets displayed a high degree of fidelity to foraging sites across years. Only one egret had $0 \%$ overlap of foraging home ranges between two consecutive years; of 26 estimates, 22 had > $50 \%$ overlap (Table 3 ). The LSM overlap was 0.74 for Reddish Egrets $(n=10)$ that nested in the upper Laguna Madre, and 0.60 for egrets $(n=3)$ that nested in the lower Laguna Madre. Foraging home ranges also overlapped among nonconsecutive years, further supporting high levels of fidelity to these sites (see Koczur 2017). Overlap of foraging home ranges between the breeding and postbreeding periods within years showed considerable variation across individuals; half of the birds had $\leq 50 \%$ overlap each year.

Reddish Egrets were documented to nest on 22 colonies in the Laguna Madre during 2010-2013 (TCWS, unpublished data). The
Fig. 3. Average distance ( $\pm 95 \%$ confidence interval) flown from the colony to foraging sites of adult Reddish Egrets (Egretta rufescens) breeding in the upper Laguna Madre, Texas, during 2010-2016. P-values for stage and sex effects are indicated above bars, differences among stages and between sexes are indicated by letters.

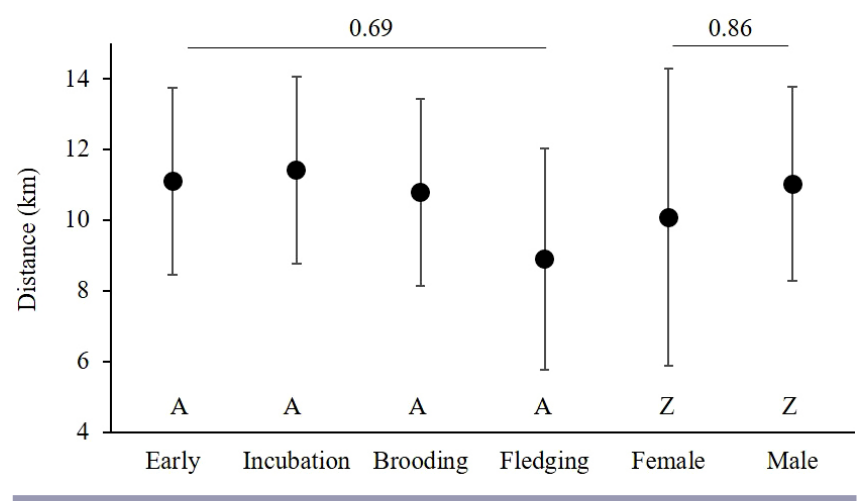

Table 3. Overlap of foraging home ranges between successive breeding seasons for 15 adult Reddish Egrets (Egretta rufescens) breeding in the Laguna Madre in 2010-2016 using Bhattacharyya's Affinity Index.

\begin{tabular}{lcccccc}
\hline \hline ID & $2010-$ & $2011-$ & $2012-$ & $2013-$ & $2014-$ & $2015-$ \\
& 2011 & 2012 & 2013 & 2014 & 2015 & 2016 \\
\hline 49148 & & 0.85 & 0.98 & 0.95 & & \\
49149 & 0.54 & 0.64 & 0.91 & 0.00 & & \\
49150 & 0.62 & 0.92 & 0.96 & & & \\
49153 & & & 0.91 & 0.87 & & \\
49154 & 0.00 & 0.93 & 0.48 & & & \\
49164 & & & 0.68 & 0.82 & 0.80 & 0.84 \\
$49166 \mathrm{~b}$ & & & & & 0.49 & \\
49194 & 0.83 & & & & & \\
49195 & & 0.46 & 0.53 & 0.92 & & \\
$49196 \mathrm{~b}$ & & & & & 0.54 & 0.80 \\
49422 & 0.80 & & 0.20 & & & \\
$49422 \mathrm{~b}$ & & & & & 0.81 & 0.77 \\
129771 & & & & & 0.74 & 0.87 \\
129772 & & & & & & \\
\hline
\end{tabular}

amount of available foraging habitat estimated to occur within $15 \mathrm{~km}$ of colonies ranged from 2618 to 29,636 ha $($ mean $=9288$ ha). Green Island consistently had the greatest number of breeding pairs and had the greatest amount of available foraging habitat within $15 \mathrm{~km}$ of the island. Area of foraging habitat was a significant predictor of the number of breeding pairs at a colony $\left(\mathrm{X}^{2}=6.45, \mathrm{df}=1, \mathrm{P}=0.011\right.$; Fig. 4). The density of competitors around each colony did not explain variation in the number of breeding Reddish Egrets in colonies $\left(\mathrm{X}^{2}=3.51\right.$, $\left.\mathrm{df}=2, \mathrm{P}=0.17\right)$.

\section{DISCUSSION}

This is the first study to examine the breeding ecology and habitat use of individual Reddish Egrets across multiple years. The breeding season is a critical period in the annual cycle and understanding overall habitat use and site fidelity is important 
Fig. 4. Results of negative-binomial generalized model showing the mean number of observed Reddish Egret (Egretta rufescens) breeding pairs and the mean ( \pm 95 confidence interval) number of predicted pairs at a colony in relation to the amount of available foraging habitat within $15 \mathrm{~km}$ of the colony. Model: Reddish Egret pairs $=$ foraging habitat + density of competitors.

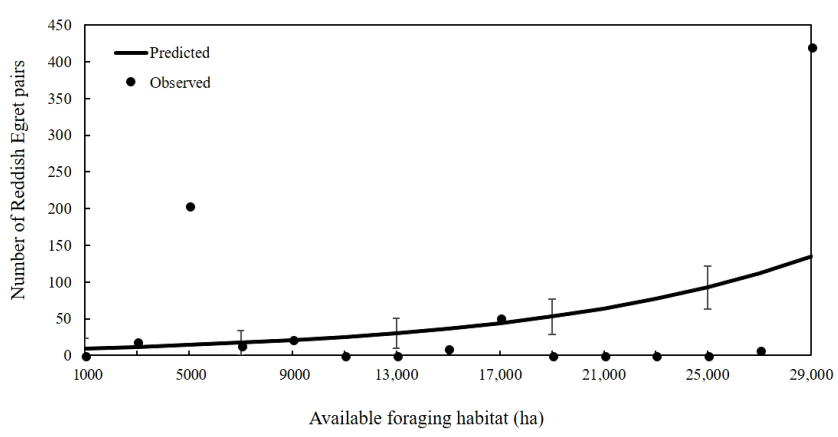

for directing conservation efforts. We found that long-distance migrant Reddish Egrets initiated nests later than individuals that remained resident; however, these differences had no measurable effects on nest success or fidelity to foraging areas.

In species that exhibit a partial migration strategy, individuals that remain resident within the breeding range are often more dominant, such as older males (Lack 1968, Lundberg 1988). Individuals that remain at the breeding area can defend a nesting site and begin breeding earlier, often leading to higher reproductive success compared to later arriving migrants (Verhulst and Tinbergen 1991). Timing of nesting is particularly important in species breeding in northern latitudes that have a relatively short breeding season and for which individuals that initiate a nest late may have lower reproductive success (Madsen et al. 2007, Meltofte et al. 2007). However, in subtropical climates like the lower Texas coast, the timing of nest initiation is not as constrained. The initiation of breeding activity based on location history of PTT-marked Reddish Egrets was similar to previous records of initiation occurring in March-April, and breeding occurring from March through June (Huysman 1995, Lowther and Paul 2002). Huysman (1995) observed peaks in nesting activity, and categorized nests initiated after 20 April as "late" nests. Previous studies of nest initiation did not take migratory status into account. The later nest initiation dates of long-distance migrants in this study are noteworthy but did not appear to influence nest success. This is consistent with findings by Holderby et al. (2012) in which they found no difference in Reddish Egret nest success between two colonies that exhibited a 38-day difference in mean nest initiation date; however, this study did not examine within colony differences in initiation. Huysman (1995) examined nest success at two colonies in the lower Laguna Madre and found higher hatching success in Reddish Egret nests that were initiated earlier. She attributed nest failures later in the season to increased rates of Laughing Gull (Leucophaeus atricilla) depredation, because the younger chicks of later nesting egrets were more susceptible to gull depredation at that time. It is unknown how fledging success and first-year survival of young are affected by nest initiation date. It should also be noted that the number of days an egret was at a colony should provide a representative index of nest success, yet many assumptions were made in determining the appropriate length of time to consider a nest successful.

Successful nesting at a site in previous years is one of the factors that influence breeding site fidelity, which is common among avian groups (Haas 1998, Hoover 2003). Although many egrets in this study nested at more than one colony during the study period, they displayed a high degree of fidelity to foraging areas, and often nested on nearby colonies that allowed access to those same foraging areas. There were no obvious factors influencing colony site fidelity; only one egret switched colonies after a failed nesting attempt the previous year, whereas others nested at different colonies after assumed success in the previous year, suggesting that there is competition for high-quality nesting sites. When egrets appeared to renest, it always occurred at a different colony than the first attempt. The degree that nest failure is a result of competition within a colony is unknown for Reddish Egrets. We observed a nest failure (abandonment) that was a result of another pair of egrets continuously stealing nesting material. Thus, the finding that a nesting pair does not return to a colony following unsuccessful or successful nesting could be a product of overall competition within a colony. This may suggest that nesting sites or nesting material may be limiting to Reddish Egrets in the Laguna Madre. Although colony stability has been recorded for several heron species (Kelly et al. 2007; TCWS, unpublished data), there is a paucity of information available on individual colony fidelity in other heron species.

Another possibility is that the specific colony is not as important as the general area that an individual uses throughout the breeding period. A band-resight study of Least Terns (Sternula antillarum) found that adult terns did not exhibit strong fidelity to the colony where they were captured; however, they did exhibit fidelity to the region, moving a median distance of $9.1 \mathrm{~km}$ from the original colony (Renken and Smith 1995). Fidelity to a particular region may be beneficial because an individual would have previous knowledge of the area, including productive foraging sites.

Reddish Egrets selected foraging habitats during the breeding period with little to no seagrass coverage. This is a characteristic of foraging habitat that has been reported during other portions of their annual cycle as well (Bates et al. 2016, Koczur 2017). A recent study on the foraging dynamics of Reddish Egrets in the Laguna Madre found that, on average, egrets foraged in areas with $<12 \%$ seagrass coverage throughout the annual cycle (Bates et al. 2016). Reddish Egrets are active foragers, and they would likely be impeded while running/chasing prey in dense seagrass. Dense seagrass also provides cover for prey, making them less detectable to actively foraging egrets. Bates and Ballard (2014) found that the rate of successful strikes by foraging Reddish Egrets decreased with increasing seagrass coverage. Foraging in areas with little seagrass cover may also reduce competition with other herons that employ a "sit and wait" foraging strategy in areas of dense seagrass. These results provide further evidence for the importance of shallow, unconsolidated flats for foraging Reddish Egrets. Although our results indicated Reddish Egrets used terrestrial sites during the presumed foraging periods, this likely resulted from egrets not actually foraging during those times, but 
instead either flying between foraging locations, or resting on the shoreline as previously documented (Bates 2011).

Our range of flight distances from the colony to foraging areas was similar to those documented in other wading bird species (Wong et al. 1999, Brzorad et al. 2015). The greatest amount of available foraging habitat was in the lower Laguna Madre (Bates et al. 2016), which also contained the largest colony. Lamb (2016) found that Brown Pelicans (Pelecanus occidentalis) breeding in larger colonies flew farther distances to foraging areas than those breeding in smaller colonies, presumably due to densitydependent prey depletion within close proximity to the colony. Smith (1995) found that Snowy Egrets and White Ibises (Eudocimus albus) flew farther to foraging areas because of high water levels. Reddish Egrets nesting in the lower Laguna Madre may have flown farther to minimize foraging competition or to reach more productive foraging sites.

Reddish Egrets exhibited a relatively high degree of fidelity to foraging areas across consecutive breeding seasons. All egrets also exhibited some degree of overlap between foraging areas used while nesting and those used postnesting. Foraging site fidelity within a breeding season has been found in a variety of species (Irons 1998, Amat et al. 2005, Kotzerka et al. 2011), whereas foraging site fidelity across breeding seasons has only recently been examined (Wakefield et al. 2015).

The availability of foraging habitat does not appear to be a limiting factor for Reddish Egrets during the breeding season in the Laguna Madre of Texas. We found a positive relationship between the number of breeding pairs of Reddish Egrets at a colony and the amount of foraging habitat near the colony, similar to findings on Great Blue Herons (Gibbs 1991). However, we also found that Reddish Egrets flew relatively long distances even when foraging habitat availability was high and density of competitors was low. This may be a function of their nomadic prey and the patchiness in its spatial distribution. Other factors that were not examined in this study may influence colony use and nest success in the Laguna Madre, such as suitable nesting habitat, human disturbance, and presence of predators. Foraging habitat during the breeding season may not limit the population currently; however, under various scenarios of sea level rise, foraging and nesting habitat are projected to be greatly impacted. In a recent analysis of habitat change in the Laguna Madre using a 1-m rise in sea level by the year 2100, Lange (2014) found that the current area of tidal flats would decrease by $83 \%$. Tidal flats are the predominant habitat type used by foraging Reddish Egrets in Texas (Lowther and Paul 2002, Bates et al. 2016).

\section{CONCLUSION}

Some of the results from this study will likely apply to other portions of the Reddish Egret's range. For example, egrets that winter in Florida exhibited a high degree of fidelity to foraging and roosting areas (Koczur 2017), therefore they may also exhibit fidelity to colonies and foraging areas during the breeding season. Other factors will need to be examined locally throughout the range. For instance, the benthic habitat at shallow foraging sites will likely differ throughout the species range (Koczur 2017). Also, the distance an egret flies from the colony to foraging sites will depend largely on the landscape characteristics within the system in which it breeds. The management of currently unused islands or creation of new breeding habitat should take the proximity of available foraging habitat into account to maximize use by breeding Reddish Egrets. This research contributes to the limited knowledge base of Reddish Egret ecology. Future research should investigate factors limiting population growth because the population in Texas is thought to be well below historic levels (Bates et al. 2009), and range-wide is below population objectives (Wilson et al. 2014). Because Reddish Egrets are a habitat specialist, management and conservation practices for the species will also benefit generalist waterbirds.

Responses to this article can be read online at: http://www.ace-eco.org/issues/responses.php/1258

\section{Acknowledgments:}

Funding was provided by the Walter Fondren, III Fellowship in Shorebird and Wading Bird Research and USFWS Migratory Bird Program Regions 2 and 4. We thank D. Wester and J. Leonard for assistance with statistical and spatial analyses. L. Brennan, F. Hernández, two anonymous reviewers, and the editor provided constructive comments for this manuscript. Trapping and banding were conducted under TAMUK IACUC Approval \#2010-03-24A and 2013-05-23, and USGS Banding Permit \#21314. This is manuscript 18-120 of the Caesar Kleberg Wildlife Research Institute.

\section{LITERATURE CITED}

Amat, J. A., M. A. Rendón, M. Rendón-Martos, A. Garrido, and J. M. Ramírez. 2005. Ranging behaviour of Greater Flamingos during the breeding and post-breeding periods: linking connectivity to biological processes. Biological Conservation 125:183-192. http://dx.doi.org/10.1016/j.biocon.2005.02.018

Bates, E. M. 2011. Foraging ecology of Reddish Egrets in the Laguna Madre of Texas. Dissertation. Texas A\&M UniversityKingsville, Kingsville, Texas, USA.

Bates, E. M., and B. M. Ballard. 2014. Factors influencing behavior and success of foraging Reddish Egrets (Egretta rufescens). Waterbirds 37:191-202. http://dx.doi.org/10.1675/063.037.0213

Bates, E. M., R. W. DeYoung, and B. M. Ballard. 2009. Genetic diversity and population structure of Reddish Egrets along the Texas coast. Waterbirds 32:430-436. http://dx.doi. org/10.1675/063.032.0308

Bates, E. M., L. M. Koczur, and B. M. Ballard. 2015. Post-fledging survival and dispersal of juvenile Reddish Egrets (Egretta rufescens). Waterbirds 38:401-406. http://dx.doi.org/10.1675/063.038.0403

Bates, E. M., L. M. Koczur, A. Krainyk, B. M. Ballard, and A. C. Kasner. 2016. Spatial and temporal dynamics of foraging habitat availability for Reddish Egrets in the Laguna Madre, Texas. International Journal of Biodiversity and Conservation 8:251-258. http://dx.doi.org/10.5897/IJBC2016.1025

BirdLife International. 2016. Egretta rufescens. The IUCN Red List of Threatened Species 2016:e.T22696916A93592693. [online] URL: http://dx.doi.org/10.2305/IUCN.UK.2016-3.RLTS.

T22696916A93592693.en 
Brzorad, J. N., A. D. Maccarone, and H. M. Stone. 2015. A telemetry-based study of Great Egret (Ardea alba) nestattendance patterns, food-provisioning rates, and foraging activity in Kansas, USA. Waterbirds 38:162-172. http://dx.doi. org/10.1675/063.038.0205

Calenge, C. 2011. Exploratory analysis of the habitat selection by the wildlife in $R$ : the adehabitatHS package. Office National de la Chasse et de la Faune Sauvage, Saint Benoist, France.

Calenge, C. 2015. Home range estimation in $R$ : the adehabitat $H R$ Package. Office National de la Chasse et de la Faune Sauvage, Saint Benoist, France.

Fieberg, J., and C. O. Kochanny. 2005. Quantifying home-range overlap: the importance of the utilization distribution. Journal of Wildlife Management 69:1346-1359. http://dx.doi.org/10.2193/0022-541X (2005)69[1346:QHOTIO]2.0.CO;2

Finkbeiner, M., J. D. Simons, C. Robinson, J. Wood, A. Summers, and C. Lopez. 2009. Atlas of shallow-water benthic habitats of coastal Texas: Espiritu Santo Bay to Lower Laguna Madre, 2004 and 2007. NOAA Coastal Services Center, Charleston, South Carolina, USA.

Gibbs, J. P. 1991. Spatial relationships between nesting colonies and foraging areas of Great Blue Herons. Auk 108:764-770.

Green, M. C. 2006. Status report and survey recommendations on the Reddish Egret (Egretta rufescens). U.S. Fish and Wildlife Service, Atlanta, Georgia, USA.

Haas, C. A. 1998. Effects of prior nesting success on site fidelity and breeding dispersal: an experimental approach. Auk 115:929-936. http://dx.doi.org/10.2307/4089511

Hill, A., and M. C. Green. 2011. Reddish Egret (Egretta rufescens) in the lower Florida Keys. Journal of Heron Biology and Conservation Art 6.

Holderby, Z., W. Simper, B. Geary, and M. C. Green. 2012. Potential factors affecting nest initiation date, clutch size and nest success in the plumage dimorphic Reddish Egret. Waterbirds 35:437-442. http://dx.doi.org/10.1675/063.035.0308

Hoover, J. P. 2003. Decision rules for site fidelity in a migratory bird, the Prothonotary Warbler. Ecology 84:416-430. http://dx. doi.org/10.1890/0012-9658(2003)084[0416:DRFSFI]2.0.CO;2

Huysman, A. P. 1995. Nesting ecology and contaminant burdens of Reddish Egrets (Egretta rufescens) of the Texas and Mexico Coasts. Thesis. North Carolina State University, Raleigh, North Carolina, USA.

Irons, D. B. 1998. Foraging area fidelity of individual seabirds in relation to tidal cycles and flock feeding. Ecology 79:647-655. http://dx.doi.org/10.1890/0012-9658(1998)079[0647:FAFOIS]2.0. $\mathrm{CO} ; 2$

Jenni, D. A. 1969. A study of the ecology of four species of herons during breeding season at Lake Alice, Alachua County, Florida. Ecological Monographs 39:245-270. http://dx.doi.org/10.2307/1948546

Kelly, J. P., K. Etienne, C. Strong, M. McCaustland, and M. L. Parkes. 2007. Status, trends, and implications for the conservation of heron and egret nesting colonies in the San Francisco Bay area. Waterbirds 30:455-478. http://dx.doi.org/10.1675/1524-4695 (2007)030[0455:STAIFT]2.0.CO;2
Kelly, J. P., D. Stralberg, K. Etienne, and M. McCaustland. 2008. Landscape influence on the quality of heron and egret colony sites. Wetlands 28:257-275. http://dx.doi.org/10.1672/07-152.1

Koczur, L. M. 2017. Movement ecology of Reddish Egrets. Dissertation. Texas A\&M University-Kingsville, Kingsville, Texas, USA.

Koczur, L. M., G. M. Kent, B. Geary, B. M. Ballard, K. D. Meyer, and M. C. Green. 2015. Measurements of adult and hatch-year Reddish Egrets (Egretta rufescens). Waterbirds 38:308-311. http:// dx.doi.org/10.1675/063.038.0312

Kotzerka, J., S. A. Hatch, and S. Garthe. 2011. Evidence for foraging-site fidelity and individual foraging behavior of Pelagic Cormorants rearing chicks in the Gulf of Alaska. Condor 113:80-88. http://dx.doi.org/10.1525/cond.2011.090158

Lack, D. 1968. Bird migration and natural selection. Oikos 19:1-9. http://dx.doi.org/10.2307/3564725

Lamb, J. S. 2016. Ecological drivers of Brown Pelican movement patterns and reproductive success in the Gulf of Mexico. Dissertation. Clemson University, Clemson, South Carolina, USA.

Lange, C. J. 2014. Influence of development and sea level rise on the conservation of Redheads along the lower Texas Coast. Thesis. Texas A\&M University-Kingsville, Kingsville, Texas, USA.

Lowther, P. E., and R. T. Paul 2002. Reddish Egret (Egretta rufescens). In A. Poole and F. B. Gill, editors. The birds of North America online. Cornell Lab of Ornithology, Ithaca, New York, USA. http://dx.doi.org/10.2173/bna.633

Lundberg, P. 1988. The evolution of partial migration in birds. Trends in Ecology \& Evolution 3:172-175. http://dx.doi. org/10.1016/0169-5347(88)90035-3

Madsen, J., M. Tamstorf, M. Klaassen, N. Eide, C. Glahder, F. Rigét, H. Nyegaard, and F. Cottaar. 2007. Effects of snow cover on the timing and success of reproduction in high-Arctic Pinkfooted Geese Anser brachyrhynchus. Polar Biology 30:1363-1372. http://dx.doi.org/10.1007/s00300-007-0296-9

Manly, B. F. J., L. L. McDonald, D. L. Thomas, T. L. McDonald, and W. P. Erickson. 2007. Resource selection by animals: statistical design and analysis for field studies. Kluwer Academic, New York, New York, USA.

McMurry, S. L. 1971. Nesting and development of the Reddish Egret (Dichromanassa rufescens Gmelin) on a spoil bank chain in the Laguna Madre. Thesis, Texas A\&M University-Kinsville, Kingsville, Texas, USA.

Meltofte, H., T. Piersma, H. Boyd, B. McCaffery, B. Ganter, V. V. Golovnyuk, K. Graham, C. L. Gratto-Trevor, R. I. G. Morrison, E. Nol, H. Rösner, D. Schamel, H. Schekkerman, M. Y. Soloviev, P. S. Tomkovich, D. M. Tracy, I. Tulp, and L. Wennerberg. 2007. Effects of climate variation on the breeding ecology of Arctic shorebirds. Bioscience 59:1-48.

Renken, R. B., and J. W. Smith. 1995. Interior Least Tern site fidelity and dispersal. Colonial Waterbirds 18:193-198. http://dx. doi.org/10.2307/1521480 
Rodgers Jr., J. A. 1980. Breeding ecology of the Little Blue Heron on the West Coast of Florida. Condor 82:164-169. http://dx.doi. org/10.2307/1367470

Simersky, B. L. 1971. Competition and nesting success of four species of herons on four spoil islands in the Laguna Madre. Thesis. Texas A\&M University-Kingsville, Kingsville, Texas, USA.

Smith, J. P. 1995. Foraging flights and habitat use of nesting wading birds (Ciconiiformes) at Lake Okeechobee, Florida. Colonial Waterbirds 18:139-158. http://dx.doi.org/10.2307/1521475

Tourenq, C., S. Benhamou, N. Sadoul, A. Sandoz, F. Mesléard, J.-L. Martin, and H. Hafner. 2004. Spatial relationships between tree-nesting heron colonies and rice fields in the Camargue, France. Auk 121:192-202. http://dx.doi.org/10.1642/0004-8038 (2004)121[0192:SRBTHC]2.0.CO;2

Tunnell, J. W., and F. W. Judd 2002. The Laguna Madre of Texas and Tamaulipas. Vol. 2. Texas A\&M University Press, College Station, Texas, USA.

Turner, A. J. 2011. Dynamics of wading bird colonies along the Texas Coast, USA. Dissertation. Texas A\&M UniversityKingsville, Kingsville, Texas, USA.

Verhulst, S., and J. M. Tinbergen. 1991. Experimental evidence for a causal relationship between timing and success of reproduction in the Great Tit Parus m. major. Journal of Animal Ecology 60:269-282. http://dx.doi.org/10.2307/5459

Wakefield, E. D., I. R. Cleasby, S. Bearhop, T. W. Bodey, R. D. Davies, P. I. Miller, J. Newton, S. C. Votier, and K. C. Hamer. 2015. Long-term individual foraging site fidelity - why some gannets don't change their spots. Ecology 96:3058-3074. http:// dx.doi.org/10.1890/14-1300.1

Wilson, T. E., J. Wheeler, M. C. Green, and E. Palacios, editors. 2014. Reddish Egret conservation action plan. Reddish Egret Conservation Planning Workshop, October 2012. Corpus Christi, Texas, USA. [online] URL: http://www.reddishegret.org/ REEG_plan_final_single.pdf

Wong, L. C., R. T. Corlett, L. Young, and J. S. Y. Lee. 1999. Foraging flights of nesting egrets and herons at a Hong Kong Egretry, South China. Waterbirds 22:424-434. http://dx.doi. org/10.2307/1522119 